\title{
Conservatism, Edmund Burke, and the Invention of a Political Tradition, c. 1885-1914
}

DOI:

$10.1017 / \mathrm{S} 0018246 \mathrm{X} 14000661$

Link to publication record in Manchester Research Explorer

\section{Citation for published version (APA):}

Jones, E. (2015). Conservatism, Edmund Burke, and the Invention of a Political Tradition, c. 1885-1914. The Historical Journal, 58(4), 1115-1139. https://doi.org/10.1017/S0018246X14000661

\section{Published in:}

The Historical Journal

\section{Citing this paper}

Please note that where the full-text provided on Manchester Research Explorer is the Author Accepted Manuscript or Proof version this may differ from the final Published version. If citing, it is advised that you check and use the publisher's definitive version.

\section{General rights}

Copyright and moral rights for the publications made accessible in the Research Explorer are retained by the authors and/or other copyright owners and it is a condition of accessing publications that users recognise and abide by the legal requirements associated with these rights.

\section{Takedown policy}

If you believe that this document breaches copyright please refer to the University of Manchester's Takedown Procedures [http://man.ac.uk/04Y6Bo] or contact uml.scholarlycommunications@manchester.ac.uk providing relevant details, so we can investigate your claim.

\section{OPEN ACCESS}




\title{
CONSERVATISM, EDMUND BURKE, AND THE INVENTION OF A POLITICAL
}

TRADITION, C.1885-1914

\author{
EMILY JONES \\ Pembroke College, University of Cambridge
}

\begin{abstract}
This article addresses the reputation of Edmund Burke and his transformation into the 'founder of modern conservatism'. It argues that this process occurred primarily between 1885 and 1914 in Britain. In doing so, this article challenges the existing orthodoxy which attributes this development to the work of Peter Stanlis, Russell Kirk, and other conservative American scholars. Moreover, this article historicizes one aspect of the construction of C/conservatism as both an intellectual (small-c) and political (capital-C) tradition. Indeed, though the late-Victorian and Edwardian period saw the construction of political traditions of an entirely novel kind, the search for 'New Conservatism' has been neglected by comparison with New Liberalism. Thus, this study explores three main themes: the impact of British debates about Irish Home Rule on Burke's reputation and status; the academic systematization of Burke's work into a 'political philosophy of conservatism'; and, finally, the appropriation of Burke by Conservative Unionists during the late-Edwardian constitutional crisis. The result is to show that by 1914 Burke had been firmly established as a 'conservative' political thinker whose work was directly associated with British Conservatism.
\end{abstract}

In 1877, the Cambridge philosopher Henry Sidgwick reflected, "though Burke lives, we meet with no Burkites." Today, Sidgwick's claim that Edmund Burke (1730-97) lacked disciples in the nineteenth century might seem like a strange one, given his canonical position in the history of political thought. ${ }^{2}$ Burke was a Whig, but modern interpretations of his thought usually place him within a small-c 'conservative' intellectual tradition, which is frequently linked to the British Conservative party. ${ }^{3}$ The standard reading of Burke's works will be familiar to historians of political thought and of modern Britain in general. Put succinctly,

\footnotetext{
${ }^{1}$ Henry Sidgwick, 'Bentham and Benthamism in politics and ethics' [1877], Miscellaneous essays and addresses, eds. E. M. and A. Sidgwick (London, 1904), p. 136.

${ }^{2}$ For intellectual and stylistic clarity, 'Conservative' is used to indicate party-political affiliation, whereas 'conservative' denotes the intellectual tradition. Where both terms are applicable ' $\mathrm{C} /$ conservative' is employed. ${ }^{3}$ One recent example is the Conservative MP Jesse Norman's Edmund Burke: philosopher, politician, prophet (London, 2013). Burke's appeal is of course much wider, and commentators on the left, such as Labour's David Marquand, have sporadically claimed inspiration: Mammon's kingdom (London, 2014). Yet Burke is still most commonly promoted as the founder of 'conservatism': Anne McElvoy's 'Conservatism: the grand tour' (BBC Radio 4, Sept. 2013) is a good popular illustration of this.
} 
'Burkean conservatism' centres round key concepts, drawn primarily from his Reflections on the revolution in France (1790), such as 'the authority of tradition', the organic, historic conception of society, and the necessity of order, religion, and property. Thus Burke, who never produced a theory of government, is now generally referred to as the 'founder of modern conservatism'.

This title was, however, awarded much later than one might expect. As James Sack has shown, Burke's legacy in the early nineteenth century was complex and ambiguous. ${ }^{4}$ For Whigs, Burke had provided the party with their 'Manual' - the Thoughts on the cause of the present discontents (1770) - but he had also split the party and, they argued, consigned them to forty years of opposition. ${ }^{5}$ At the same time, Burke was held up by Tories as an anti-French totem, yet his primary political identity was not forgotten: as late as 1873 Disraeli could describe Burke as the 'arch-Whig trumpeter' who had inspired Pitt's 'Whiggish' war against Revolutionary France. ${ }^{6}$ Intense praise for Burke's literary qualities was in fact often used to counterbalance more serious charges: he was an Irish adventurer, a deathbed Catholic convert, and heavily in debt. ${ }^{7}$ But perhaps the most famous conundrum - one which still resonates in modern academic discussions of Burke's thought - was the question of Burke's consistency. It was typical to divide Burke's writings into two phases: the early works, such as Present discontents and the speeches on the American colonies; and the later works on Revolutionary France. ${ }^{8}$ His political legacy was thus divided between Whig exaltation of earlier texts, and

\footnotetext{
${ }^{4}$ J. J. Sack, 'The memory of Pitt and the memory of Burke: English Conservatism confronts its past, 1806-29', Historical Journal, 30 (1987), pp. 623-40.

${ }^{5}$ A. H. Hallam, 'Burke', Gallery of portraits (7 vols., London, 1833-7), III, p. 35; Lord John Russell, The life and times of Charles James Fox (3 vols., London, 1859-66), III, pp. 122-26.

${ }^{6}$ W. F. Monypenny and G. E. Buckle, Life of Benjamin Disraeli, earl of Beaconsfield (6 vols., London, 191020), II, p. 297.

${ }^{7}$ For a succinct catalogue, see John Morley, Burke (London, 1879), pp. 91-93. The later Namierite dislike of Burke certainly had a precedent. For Namier and Burke, see James Smyth, 'Lewis Namier, Herbert Butterfield and Edmund Burke', Journal of Eighteenth Century Studies, 35 (2012), pp. 381-9.

${ }^{8}$ See for example, Thomas Moore, Life of Richard Sheridan, $3^{\text {rd }}$ edn. (2 vols., London, 1825), II, p. 98-9; Gladstone to G. W. E. Russell, 13 Oct. 1884, Correspondence on church and religion of W. E. Gladstone, ed. D. C. Lathbury (2 vols., London, 1910), II, p. 326.
} 
Tory adulation of Reflections. Henry Thomas Buckle, in his well-known History of civilization in England, went so far as to argue that the French Revolution had simply driven Burke mad. ${ }^{9}$ The result was an unclear political identity, and this led Conor Cruise O'Brien to note that Burke was more widely admired amongst Liberals than Conservatives in nineteenth-century Britain. ${ }^{10}$ Indeed, some of the most prominent commentary on Burke before 1885 was produced by Leslie and James Fitzjames Stephen, John Morley, Matthew Arnold, and W. E. H. Lecky all of them Liberals, though of quite different kinds. How, then, did a politically-murky 'mad' Irish Whig come to be seen as the 'founder of modern conservatism' with the Reflections as its bible?

Since the 1950s, prominent Burke scholars have styled nineteenth-century interpretations of Burke as 'liberal utilitarian'. ${ }^{11}$ Morley, the advanced Liberal who published two significant books on Burke in 1867 and 1879, is singled out as appropriating Burke in this way. It was then left to Cold War American conservatives - most notably Russell Kirk and Peter Stanlis - to rescue Burke as a 'conservative' political thinker. ${ }^{12}$ This story, however, by omitting contextual engagement with British intellectual and political history, fails to recognize the centrality of Burke in intervening discussions of C/conservatism. Morley himself described the twin pillars in Burke's thought as 'utilitarian liberalism' and 'historic conservatism' in

\footnotetext{
${ }^{9}$ H. T. Buckle, History of civilization in England, (2 vols., London, 1857-61), I, pp. 424-32.

${ }^{10}$ Edmund Burke, Irish affairs, eds. Matthew Arnold [1881] and Conor Cruise O'Brien (London, 1988). John Burrow's Whigs and Liberals: continuity and change in English political thought (Oxford, 1988) traced perceived 'Burkeanisms' through significant nineteenth-century thinkers, but this was based on retrospectively detected affinity or resemblance, rather than the actual attestable influence or admiration of Burke and his works.

${ }^{11}$ Drew Maciag, Edmund Burke in America: the contested career of the father of modern conservatism (New York, 2013), p. 109; David Dwan and Christopher Insole, 'Introduction', in The Cambridge companion to Edmund Burke, eds. idem. (Cambridge, 2012), pp. 7, 13n3; Isaac Kramnick, The rage of Edmund Burke: portrait of an ambivalent conservative (New York, 1977), pp. 41, 46. See also, for example, Peter Stanlis, Edmund Burke and the natural law (Ann Arbour, 1958).

${ }^{12}$ Maciag, Edmund Burke in America, p. 166, 172-99. The emphasis Stanlis and Kirk placed on natural law was, however, contentious: see the comments on Gertrude Himmelfarb in ibid., pp. 196-99.
} 
1879. ${ }^{13}$ Moreover, it was 'historic conservatism' which gained greater traction in the years after 1885. From this point, Burke's thought was increasingly systematized into a 'political philosophy of conservatism' to match the dramatically altered political and intellectual landscape of the late-Victorian and Edwardian period.

It has long been suggested that the fin-de-siècle period gave birth to a variety of invented national historical traditions. ${ }^{14}$ Although this has not gone uncontested, certainly, in specifically political terms, it was a period of flux and uncertainty: numerous commentators predicted the break-up of the parliamentary two-party system as the historic constitutional divisions which had structured political debate since 1832 began to dissolve in the wake of the 1884-5 Reform Acts and the debates over Irish Home Rule. Across the political spectrum frantic searches were conducted for new intellectually and historically grounded identities and genealogies to suit the altered context: hence the magnetic attraction of an extra-constitutional social and economic agenda to 'New Liberalism'. It was a momentous period in the history of British political thought and party politics. Yet - in comparison to the extensive scholarship on Liberalism and Socialism in this period - the construction of a political and intellectual 'New Conservatism' has been overlooked. ${ }^{15}$ This is a deficit of some consequence, because it is just as clear that Conservatism, as a (capital-C) British party-political tradition, underwent a substantial intellectual makeover between 1885 and 1914.

\footnotetext{
${ }^{13}$ Morley, Burke, p. 213.

${ }^{14}$ Paul Readman, 'The place of the past in English culture, c.1890-1914', Past and Present, 186 (2005), pp. 147-99; Stefan Collini, Public moralists: political thought and intellectual life in Britain, 1850-1930 (Oxford, 1992), ch. 9; Jose Harris, Private lives, public spirit: a social history of Britain, 1870-1914 (Oxford, 1993), p. 33; Eric Hobsbawn, 'Mass-producing traditions: Europe, 1870-1914', in eds. Eric Hobsbawn and Terence Ranger, The invention of tradition (Cambridge, 1983); David Cannadine, 'The context, performance and meaning of ritual: the British monarchy and the "invention of tradition", c.1820-1977', in ibid., pp. 101-38. 15 The prolific work of Michael Freeden on Liberalism has been especially influential: The New Liberalism: an ideology of social reform (Oxford, 1978); Liberalism divided: a study in social thought, 1914-1939 (Oxford, 1986). See also Ben Jackson and Marc Stears, eds., Liberalism as ideology: essays in honour of Michael Freeden (Oxford, 2012).
} 
One crucial part of the intellectual history of C/conservatism in Britain in this period was the establishment of Burke in the recognizably modern sense as 'the founder of conservatism'. Observing the historical canonization of Burke serves a dual purpose: besides being a fundamental re-working of Burke's personal posthumous reception history, it provides a sustained insight into the considerable intellectual work done by Conservatives and Liberal Unionists as they rethought their political traditions over a thirty-year period. This article will therefore address three significant themes which moulded Burke's thought into a much baggier, but more polemically useful, 'theory' of conservatism, which eventually became seen as the basis of political Conservatism. These are as follows: the impact of the 1886 Irish Home Rule debates on Burke's reputation and status; the burgeoning literature in higher education which sought to systematize Burke's letters and speeches into what was increasingly described as a 'political philosophy of conservatism'; and the simultaneous appropriation of Burke's 'conservatism' by a substantial number of political Conservatives.

The 1886 Irish Home Rule Bill, which sought to establish a separate parliament in Dublin, would also (its opponents claimed) have undermined the historically unitary conception of parliamentary sovereignty. It was a major constitutional issue which permanently reformed party-political divisions, and historians of Home Rule have noted that Burke was a fundamental intellectual component of the debates in Britain from at least $1885 .{ }^{16}$ Conversely, the Home Rule debates were a unique moment in Burke's reception history, as alternative interpretations

\footnotetext{
${ }^{16}$ Paul Bew, Ireland: the politics of enmity, 1789-2006 (Oxford, 2009), p. 349; J. Loughlin, Gladstone and the Ulster question, 1882-1893 (Dublin, 1986), pp. 59, 195; Patrick Maume 'Burke in Belfast: Thomas MacKnight, Gladstone and Liberal Unionism', in D. G. Boyce and Alan O'Day, Gladstone and Ireland: politics, religion and nationality in the Victorian age (London, 2010).
} 
of Burke's thought were contested in parliament, in the press, in pamphlets, in books, and on speaking tours. A considerable British audience was presented with explicit statements of Burke's relevance to pressing contemporary political problems.

Gladstone's conversion to the cause of Home Rule in December 1885 was the first and single most important event here. As John Morley’s 1903 Life of Gladstone stressed, Gladstone was reading Burke almost daily at this point. ${ }^{17}$ The Gladstone diaries confirm that, during December 1885, Gladstone was reading Burke constantly, particularly his speeches on the American colonies. ${ }^{18}$ On $13^{\text {th }}$ April 1886, Gladstone called on parliament to utilize Burke in their considerations of Home Rule:

I should like to quote Mr. Burke — and I hope we shall hear much of Mr. Burke in the course of this discussion - for the writings of Mr. Burke upon Ireland, and still more upon America, are a mine of gold for the political wisdom with which they are charged, applicable to the circumstances of to-day, and full of the deepest and most valuable lessons to guide the policy of a country. ${ }^{19}$

Concentrating primarily on these Irish and American texts, Gladstone drew an argument for constitutional change from Burke. This lay in an understanding of Irish history and character, and on an insistence on a 'union of hearts', or voluntary political ties between British dominions. The Gladstonian argument with reference to Burke covered four main points: the

\footnotetext{
${ }^{17}$ John Morley, Life of Gladstone, (3 vols., London, 1903), III, p. 280.

${ }^{18}$ M. R. D. Foot and H. C. G. Matthew, The Gladstone diaries, (14 vols., Oxford, 1968-1996), XI, pp. $443-54$. 'Burke on America' was generally considered to consist of the speeches on taxation (1774) and conciliation (1775).

${ }^{19}$ Hansard (hereafter $H$ ) HC Deb, 13 Apr. 1886, vol. 304, cc.1439-550, 1544-45. Gladstone also closed the debates with Burke: H HC Deb, 07 June 1886, vol. 306, cc.1145-245, 1221, 1237.
} 
importance of voluntary political ties in maintaining the Union; the stark choice between Home Rule and coercion; the idea that Home Rule was a final measure and would not lead to separation; and the significance of Grattan's Parliament (a Protestant legislature in Dublin in existence from 1782 until the enactment of the Union in 1801) in providing an historical and constitutional precedent for devolution. Here was Burke the Irish Whig - and most certainly not the founder of modern conservatism.

Gladstone's arguments and use of Burke guided many of his supporters and allies, both inside and outside of Westminster. They included the Chancellor William Harcourt, ${ }^{20}$ the Home Secretary Hugh Childers, ${ }^{21}$ the Irish Parliamentary Party MP John Redmond, ${ }^{22}$ backbench Liberals such as Lyon Playfair, George Shaw-Lefevre, and Alfred Pease, ${ }^{23}$ plus numerous pamphlets and speeches, ${ }^{24}$ the Handbook for Home Rule (edited by James Bryce), ${ }^{25}$ and letters to newspapers, particularly The Times. ${ }^{26}$ Yet the Gladstonian use of Burke was not entirely successful. The idea that voluntary political ties were the essence of Burke's political thought was at odds with existing interpretations, including those of Liberals. Even Morley, an ardent Gladstonian, had instead emphasised Burke's rigid adherence to the 1688 constitution $^{27}$ - and one of the most telling signs of the weakness of the Gladstonian utilization of Burke was

\footnotetext{
${ }^{20}$ H HC Deb 13 Apr. 1886, vol. 304, cc.1439-550, 1454-1455; HC Deb, 1 June 1886, vol. 306, cc.675-780, 762.

${ }^{21} H$ HC Deb, 21 May 1886, vol. 305, cc.1667-780, 1742.

${ }^{22}$ H HC Deb, 13 May 1886, vol. 305, cc.912-1023, 968.

${ }^{23}$ H HC Deb, 18 May 1886, vol. 305, cc.1299-385, 1314-1315 (Lefevre), 1380 (Playfair); Alfred E. Pease, Elections and recollections, (London, 1932), pp. 100, 156.

${ }^{24}$ [Anon.], 'A few extracts from the works and speeches of Edmund Burke, in support of the case of present policy of the Liberal party towards Ireland' (London, 1887). Examples of Liberal pamphlets which were published and distributed (many through official channels) which evoked Burke on the 'union of hearts', Irish history and Grattan's Parliament include: Malcolm MacColl, 'Reasons for Home Rule' (London, 1886); H. J. Leech, 'Henry Grattan: A Lecture' (London, 1886); J. Hirst Hollowell, 'Ireland: the story of her wrongs, and a plea for her rights' (Nottingham, 1886).

${ }^{25}$ R. B. O’Brien, 'The Unionist case for Home Rule' and Lord Thring, 'Home Rule and Imperial unity', in Handbook for Home Rule, ed. James Bryce, $2^{\text {nd }}$ edn. (London, 1887).

${ }^{26}$ A. J. Mundella, 'Mr. Gladstone and Burke', The Times (14 Dec. 1886), p. 10.

${ }^{27}$ Morley, Burke, pp. 86-87.
} 
the fact that Morley (then the leading authority on Burke's life and thought) never cited him in defence of the Home Rule proposals. ${ }^{28}$

The Liberal Unionists, who split from the Gladstonians over Home Rule, were not convinced either. Prominent figures such as Lecky, A. V. Dicey, and Matthew Arnold claimed Burke as their own, and not only to argue against proposed constitutional change. ${ }^{29}$ The rallying-cry of the Liberals and, before them, the Whigs, had always been 'civil and religious liberty': Liberal Unionists looked to Burke's wider oeuvre to show their adherence to this tradition - and Gladstone's apostasy from it - particularly as regards the defence of the Protestant minority in a largely Catholic Ireland. They also argued that Grattan's Parliament was an invalid precedent for nineteenth-century Home Rule as it was an assembly of loyal Protestant landlords, quoting from Burke's later writings from the 1790s which expressed his fears of separation from Westminster. ${ }^{30}$ For example, Lecky argued that Home Rule meant not liberty but 'Rome Rule', whilst Dicey defended the existing constitution against revolutionary 'Jacobins' in various books and articles. ${ }^{31}$ In these texts, Burke's Reflections, a defence of the liberty of aristocrats and clergymen against atheists and the multitude as well as a eulogy of

\footnotetext{
${ }^{28}$ Though he was not averse to doing so elsewhere: Morley's On Compromise (London, 1874) stated that Burke's definition of 'compromise' was the 'true' definition (pp. 177-78). For Morley on Burke's constitutional thought in 1886, see 'Maine on Popular Government', Fortnightly Review (Feb. 1886), pp. 153-73, at pp.15657.

${ }^{29}$ For instance, Matthew Arnold, On Home Rule for Ireland: two letters to The Times [22 May and 6 Aug. 1886], (London, 1891), pp. 4-5. On the intellectual significance of Liberal Unionism, see Ian Cawood, The Liberal Unionist party (London, 2012), p. 13; Christopher Harvie, 'Ideology and Home Rule: James Bryce, A. V. Dicey, and Ireland, 1880-1887', English Historical Review, 359 (1976), pp. 298-314; John Roach, 'Liberalism and the Victorian intelligentsia', Historical Journal, 8 (1957), pp. 71-88.

${ }^{30}$ Grattan's Parliament: a letter by Mr.W. E. H. Lecky, addressed to the editor of the Times, June 71886 (London, 1887); Duke of Argyll, $H$ HL Deb 10 June 1886, vol. 306, cc.1260-89, 1266-7.

${ }^{31}$ W. E. H. Lecky, Leaders of public opinion in Ireland, $2^{\text {nd }}$ ed. (London, 1871), p. 109; idem., History of England in the eighteenth century, (8 vols., London, 1878-90), III, pp. 212-213. He was still asserting this in 1897: Elisabeth van Dedem Lecky, A memoir of W. E. H. Lecky (London, 1909), p. 309. For Dicey, see England's case against Home Rule (London, 1886), p. 22; Why England maintains the union (London, 1887), p. 50; A leap in the dark, or, our new constitution (London, 1893; $2^{\text {nd }}$ ed., 1911), p. 134; A fool's paradise: being a constitutionalist's criticism of the Home Rule Bill of 1912 (London, 1913), pp. 95, 113.
} 
the British constitution, became a key source. ${ }^{32}$ The Fortnightly Review claimed: 'It is the fashion in these days to quote Burke. ${ }^{33}$ In this perspective, Home Rulers became French Jacobins, intent on destruction and not reform.

The historical analogy with the French Revolution became even more important as Liberal Unionists began to see the history of the 1790s repeating itself in the 1880s. The Liberal Unionists were Burke and his allies the Portland Whigs; the Gladstonians were the Foxite Whigs who sided with the revolutionaries. They thus established an historical parallel which implied that they were the true heirs of Burke, and also suggested a future connection with those traditionally considered their opponents: the Conservatives (here construed as the Pittites). In 1886 it was mostly Liberal Unionists who attempted to reclaim Burke. The only Conservative who quoted Burke in Parliament during the first Bill was Disraeli's old friend, Lord John Manners. ${ }^{34}$ Lord Salisbury appears to have kept Burke at a distance in his political thinking. ${ }^{35}$ In contrast, Liberals Unionists - like Burke - were branded traitors by the Gladstonians, causing them to retort that they remained true to their long-held political convictions. Burke's 1791 Appeal from the new to the old Whigs, which defended his adherence to 'old Whig' principles, took on a new meaning - particularly as it became clear that the Liberal split was going to be permanent. Lecky signed off letters as an 'Old Whig', ${ }^{36}$ and even Joseph Chamberlain claimed inspiration in a speech of 1889: 'I am inclined to imitate Mr.

\footnotetext{
${ }^{32}$ Maume, 'Burke in Belfast', pp. 163-64.

${ }^{33}$ [Frank Harris], 'Home affairs: a national party', Fortnightly Review (Jul 1887), pp. 140-151, at p.151.

${ }^{34} \mathrm{H}$ HC Deb, 31 May 1886, vol. 306, cc.506-90, 527.

35 J. J. Sack, 'Edmund Burke and the Conservative party', in Ian Crowe, Edmund Burke: his life and legacy (Dublin, 1997), p. 81. Burke is not discussed in Michael Bentley, Lord Salisbury's world: Conservative environments in late-Victorian Britain (Cambridge, 2001), nor Andrew Roberts, Salisbury: Victorian titan (London, 1999), which instead notes Salisbury's preference for Castlereagh (p. 50, passim.) Michael PintoDuschinsky's The political thought of Lord Salisbury, 1858-1868 (London, 1967) concludes by explicitly contrasting the 'Conservatism' of Burke and Salisbury (p. 153).

${ }^{36}$ The Times (4 Feb. 1886), qu. in Donal McCartney, W. E. H. Lecky: historian and politician, 1838-1903 (Dublin, 1994), p. 126.
} 
Burke ... and make an appeal from the new Radicals to the old. ${ }^{37}$ The effect of these historical associations was to attach what Dicey described as the 'spirit' of Burke to the Liberal Unionists, thereby detaching him from the Gladstonians, who were seen to have been radically misguided in their interpretation of Burke as a constitutional modernizer. ${ }^{38}$

As a result, Gladstonians began to loosen their ties with Burke. Harcourt, in 1892, acknowledged that it was the Liberal Unionists who now claimed to represent the principles of Burke. ${ }^{39}$ At the same time, significant Conservative appropriation of Burke on Home Rule began to emerge. Burke began to appear in Conservative arguments against the Second Home Rule Bill in parliament, including those of Balfour, ${ }^{40}$ backbench MPs,${ }^{41}$ Lord Cranbrook and William Boyd Carpenter, bishop of Ripon. Cranbrook, who served in Conservative ministries under Derby, Disraeli, and Salisbury, made use of Burke's Irish letters to insist on the disaster that total separation would bring to both Ireland and Britain, before asserting that Home Rule would inevitably lead to this. Shortly afterwards, Ripon used Burke's idea of the British parliament as a national institution, void of local attachments ('Speech to the electors of Bristol', 1774), as a refutation of the interpretation of Burke as supportive of an Irish parliament governing on Irish issues by 'Irish ideas'. ${ }^{42}$ This was a great sea-change: the Home Rule debates had convincingly re-imagined Burke as a proto-Liberal Unionist, agreeable to and allied with Conservatives. ${ }^{43}$ But this was just the beginning, and further intellectual work was required in order to transform a proto-Liberal Unionist into the founder of modern conservatism. For this

\footnotetext{
37 'Mr. Chamberlain at Greenwich', The Times (1 Aug. 1889), p. 6.

${ }^{38}$ A. V. Dicey, 'Old Jacobinism and new morality', Contemporary Review (Apr. 1888), pp. 475-502, at pp. 476, 485-6.

${ }^{39} H$ HC Deb, 09 Feb. 1892, vol. 1, cc.43-116, 69-70.

${ }^{40} H$ HC Deb, 21 Apr. 1893, vol. 11, cc.912-1007, 990-991.

${ }^{41}$ Percy Thornton, $H$ HC Deb, 14 Feb. 1893, vol. 8, cc.1399-489, 1448; T. G. Bowles, $H$ HC Deb, 14 Aug. 1893, vol. 16, cc.139-234, 193.

${ }^{42}$ H HL Deb, 08 Sept. 1893, vol. 17, cc.563-649, 574 (Cranbrook), 611 (Ripon).

${ }^{43}$ There was, from 1895, a Unionist alliance between Liberal Unionists and Conservatives, formalized in 1912 by the creation of the Conservative and Unionist Party.
} 
we must turn to broader developments in late-Victorian thought and their impact on interpretations of Burke's work.

\section{II}

It is from the 1890 s that Burke's work began to be systematized into a 'political theory', especially within university cultures. The historical and biographical scholarship written during the first three-quarters of the century was now superseded by more abstract expositions of Burke's thought. Even the language was novel: the very idea that Burke could have a 'political theory' is partly explained by the fact that many of those interested in Burke increasingly came from moral sciences and philosophy backgrounds, including Oxford 'Greats' (a degree which comprised not only the classics but philosophy, ancient and modern). Precisely because Burke did not produce a theory of government, there was much more room for interpretive construction. Hence a political philosophy of 'conservatism' was extracted from Burke's corpus, especially Reflections. And whilst it was claimed that this philosophy could be traced throughout his work, more exclusive concentration on his anti-revolutionary writings was defended by claiming that the French Revolution forced him to articulate his principles most explicitly. Thus 'Burkean conservatism' came to symbolize relatively vague concepts, such as hostility to constitutional change (including the critique of abstract ahistorical thought in politics, and the need for balance in the constitution), and support for private property, religion, historicism, and the organic nature of society. It is important to note, however, that this 'theory' was still a long way from pure philosophy: the terms were used loosely, but they were nonetheless attractive (and useful) in an English intellectual climate wary of French-sounding abstractions. ${ }^{44}$

\footnotetext{
${ }^{44}$ I use the terms 'theory', 'philosophy', and 'doctrine' synonymously, as did Burke's interpreters.
} 
The intellectual context in which Burke's ascent occurred was that of late nineteenthcentury historicism. It is well-established that the nineteenth century was extraordinarily historically-minded. 'The historical method' stressed the complexity and interdependence of institutions, beliefs and habits. This was, more often than not, linked with the organic metaphor that societies are not made, but grow. ${ }^{45}$ According to Morley in 1879:

The historic method, fitting in with certain dominant conceptions in the region of natural science, is bringing men round to a way of looking at society for which Burke's maxims are exactly suited; and it seems probable that he will be more frequently and more seriously referred to within the next twenty years than he has been within the last eighty. ${ }^{46}$

Other significant commentators who established the connection between Burke and organic historicism were Leslie Stephen and the jurist Sir Frederick Pollock. Stephen's 1876 History of English thought in the eighteenth century had made Burke an exemplar of this approach: 'Burke's magnificent imagination and true historical insight led him more than any of his contemporaries, and even than any of his successors in English political life, to a genuine historical theory. ${ }^{47}$ In an 1893 article on Thomas Paine, Stephen remarked that the 'whole pith of Burke's teaching' (and the key to his consistency) lay in the historical method - a sentiment

\footnotetext{
${ }^{45}$ Stefan Collini, John Burrow, Donald Winch, That noble science of politics: a study in nineteenth-century intellectual history (Cambridge, 1983), ch. 6.

${ }^{46}$ Morley, Burke, p. 315.

${ }^{47}$ Leslie Stephen, History of English thought in the eighteenth century (2 vols., London, 1876), II, p. 280.
} 
which he would stress again in his 1903 Ford Lectures. ${ }^{48}$ Similarly Pollock's Introduction to the science of politics (1890) was instrumental in placing Burke at the root of an international tradition of historical thought which included the jurisprudence of Savigny and Henry Maine. At the same time, Pollock believed that Burke's 1791 Appeal, in which he defended his own consistency, brought him close to an explicit statement of his 'formal theory of politics', although, despite this, Burke (just as Sidgwick had said some years earlier) 'left no disciples.' 49 Burke's legacy was ripe for picking.

One of the first attempts to produce a systematic work of political philosophy featuring Burke was William Graham's English political philosophy, from Hobbes to Maine (1899). Graham, Professor of Jurisprudence and Political Economy at Queen's, Belfast, was also wellintegrated in London society. ${ }^{50}$ He was steeped in Idealist philosophy and explicitly sought 'a connected political thought' which would illustrate its 'different schools': 'Conservative, Liberal, Radical, and ... Socialist. ${ }^{51}$ Burke had opposed parliamentary reform, extension of the franchise, and the relief of Dissenters and was, therefore, 'nothing of a Democrat, but merely a Whig with Conservative instincts, whom Dr. Johnson believed to be a Tory at heart. ${ }^{52}$ The political philosophy expounded in Reflections and the Appeal constituted 'something like a complete and coherent political system with a political doctrine. ${ }^{53}$ This Conservative 'theory' was a justification of established government, religion and property based on prescription, regardless of injustices. Graham did not argue for Burke's inconsistency, but rather that the

\footnotetext{
${ }^{48}$ Idem., 'Science and politics' [1892], Social rights and duties [1896], (2 vols., Cambridge, 2011), I, p. 46; idem., 'Thomas Paine', Fortnightly Review (Aug. 1893), pp. 267-81, at p. 273; idem., English literature in the eighteenth century (London, 1904), p. 198.

${ }^{49}$ Frederick Pollock, Introduction to the science of politics (London, 1890), pp. 84-92, 118.

${ }^{50}$ John Rae, 'Graham, William (1839-1911)', rev. C. A. Creffield, $O D N B$.

${ }^{51}$ William Graham, English political philosophy, from Hobbes to Maine (London, 1899), pp. 101, 107. See also his Idealism: an essay metaphysical and critical (London, 1892), in which his 'chief object' was to defend the Idealism of Berkeley (p. xii), and its extension by Hegel (p. xvi).

${ }^{52}$ Ibid., p. 90.

${ }^{53}$ Ibid., p. 94.
} 
French Revolution 'shook his nature.' The result 'furnished a new creed or body of principles for the Tory party, as well as a definite practical policy.' It was superior to Bolingbroke's 'unenlightened' Patriot King as it gave Tories 'new and more reasonable principles' (meaning 'maintenance of the constitution' rather than 'passive obedience'). ${ }^{54}$ English political philosophy was well-received as a contribution to the 'history of ideas', and the socialist Oxford philosopher Sidney Ball described the book as 'the most convenient introduction to English political philosophy that exists. ${ }^{55}$ However, the Saturday Review remained sceptical as to whether such an un-English thing as 'political philosophy' existed at all. ${ }^{56}$

The systematization of Burke's thought was also underway in Cambridge, and one very notable example is the young John Maynard Keynes's 1904 prize-winning essay, The political doctrines of Edmund Burke. Keynes had read Burke at Eton in 1901, and his biographer states that Burke was the only political hero he ever acknowledged as such. ${ }^{57}$ Yet our interest here is not Keynes himself but his motivation: frustrated with deficiencies in existing material, he too was driven to produce a theoretical 'political philosophy' from Burke's writings, explicitly rejecting the historical method in favour of the abstract: 'Burke is perhaps the only political writer, the direct bearing of whose works is wholly topical and contemporary, who could be approached as the source of a consistent and coherent body of political theory.' ${ }^{58}$ Keynes's essay is a forceful argument for Burke's belief in intrinsic and universal goods: the organic constitution, religion and the necessity of church establishment, and 'the sanctity of property'.

\footnotetext{
${ }^{54}$ Ibid., p. 174 .

${ }^{55}$ Athenaeum (2 Dec. 1899), p. 754; Sidney Ball, 'English political philosophy', International Journal of Ethics (Jul. 1900), pp. 520-25. See also Academy (16 Dec. 1899), pp. 720-21; 'H. B.' [Hilaire Belloc], 'English political philosophy', Speaker (16 Dec. 1899), pp. 289-90; Carveth Read, 'English political philosophy', Economic Journal (Mar. 1900), pp. 83-85.

${ }^{56}$ Saturday Review (20 Jan. 1900), pp. 83-84.

${ }^{57}$ Robert Skidelsky, John Maynard Keynes, (3 vols., London, 1983-2001), I, pp. 98n, 101, 154.

${ }^{58}$ John Maynard Keynes, The political doctrines of Edmund Burke (1904), Keynes Papers, King's College Library, Cambridge, JMK/UA/3/4; JMK/UA/20/2/94. From the unpublished writings of J.M. Keynes copyright The Provost and Scholars of King's College, Cambridge, 2014.
} 
Like Graham, Keynes stated that Burke held these beliefs whilst destroying what remained of divine right, but did not assign Burke to a particular 'school' of political thought. ' $^{59}$ Nonetheless, he developed an a priori philosophy of Burke's 'political doctrines' which emphasized the same themes as Graham's 'Conservative' theory above.

The idea of Burke's ‘political philosophy' was further developed in John MacCunn's The political philosophy of Edmund Burke (1913). MacCunn, a Snell exhibitioner tutored by Edward Caird at Glasgow and T. H. Green at Balliol, went on to become Professor of Philosophy at Liverpool. At Liverpool, MacCunn's academic and extramural pursuits reflected his preoccupation with the idea, derived from Green and Mazzini, of the nation as an 'organic whole' and revealed a typically Liberal Idealist concern for the organic growth of the nation, particularly with regards to active, ethical citizenship and the related issue of how individuals connected to communities and the state. ${ }^{60}$ Thus, MacCunn became increasingly interested in what he perceived to be Burke's organic historic political theory. Indeed, MacCunn had previously stated, in 1907, that Green instructed his students to read Burke, and MacCunn's evident respect for Burke sets the tone of his whole book. ${ }^{61}$ In ascribing Burke his own 'political philosophy', however, MacCunn felt constrained to paint Burke as a 'conservative', devoting an entire chapter to the subject.

\footnotetext{
59 JMK/UA/20/3/84.

${ }^{60}$ MacCunn, The ethics of citizenship (Glasgow, 1894); Liverpool addresses on the ethics of social Work, (Liverpool and London, 1911). For MacCunn and citizenship, see H. S. Jones, 'Education for citizenship in Great Britain, c. 1880-1944: the renewal of a civic tradition', in eds. Inge Botteri, Elena Riva, Adolfo Scotto di Luzio, Fare il cittadino. La formazione di un nuovo soggetto sociale nell'Europa tra XIX et XXI secolo (Soveria Mannelli, 2012). For the longer intellectual context of 'Liberal Anglican' conceptions of the nation, see idem., 'The idea of the national in Victorian political thought', European Journal of Political Theory, 5 (2006), pp. 12-21.

${ }^{61}$ John MacCunn, Six radical thinkers (London, 1907), p. 229. MacCunn was not the only 'second-generation' Idealist to discuss Burke, but he did so at the greatest length. See also Henry Jones, 'Wales and its prospects' (Wrexham, 1889); D. G. Ritchie, The principles of state interference (London, 1891), pp. 72-73; idem, Darwin and Hegel (London, 1893), p. 65; idem., Natural rights, $2^{\text {nd }}$ edn (London, 1903), pp. 5-6, 10, 12, 17.
} 
MacCunn also still felt it necessary to justify the idea that Burke had a 'political philosophy'. Like Graham and Keynes, MacCunn asserted that Burke was a theorist because Burke's 'conservatism' could be traced to 'philosophical principles' rather than sentiment or prejudice. ${ }^{62}$ But he criticized those who would canonize Burke as an inductive historical thinker, with Reflections the first deployment of the historical method in Britain. Instead, he claimed that Burke was a deductive thinker whose thought was based on his religion: 'What else can be said of a thinker who not only avows a passionate theistic creed, but applies this creed with such assiduity that neither his conservative faith nor his conservative fear can be adequately understood apart from it? ${ }^{63}$ To MacCunn this was to be applauded. Shifting his focus to 1913, MacCunn supported Burke's 'plea' to ally citizenship with a broad Christian faith: whilst some had sought to replace religion with 'the Nation' and 'Humanity', these were - in Burke - all part of one indivisible whole. ${ }^{64}$

Furthermore, MacCunn aimed to demonstrate that Burke's deductive political philosophy could not be described as utilitarian, as suggested in part by Morley. It was a misnomer, we are told, to construe Burke's work in this light, since 'the greatest happiness of the people' in Burke's thought was quite different from Bentham's numerical conception. ${ }^{65}$ Instead, Burke's profoundly theistic political philosophy was embedded in Whig political theory. Thus, Burke's non-elective (undemocratic) conception of representation was 'the Whig theory of political trusteeship' which catered for an elite 'public' of 400,000 men who were represented by their MPs, peers, and the monarch in the mixed constitution, and was alternatively titled 'virtual representation' ${ }^{66}$ At its basis was the belief in the natural inequality

\footnotetext{
${ }^{62}$ John MacCunn, The political philosophy of Burke (London, 1913), pp. 68.

${ }^{63}$ Ibid., p. 85.

${ }^{64}$ Ibid., pp. 132, 140-41.

${ }^{65}$ Ibid., p. 49.

${ }^{66}$ Ibid., p. 165.
} 
of men, though it could still coexist with deeply held moral sympathies with mankind. ${ }^{67}$ Burke's political thought was rooted to this: 'Burke's theory of government $\ldots$ had its foundations deeply laid in his conception of a people, and in the profoundly conservative principles deduced therefrom. ${ }^{68}$ Once more it was his Whiggishness that made him a modern conservative: Burke's love of defending the constitution made him 'by far the greatest of conservatives' without being a 'worshipper of kings.' ${ }^{69}$

MacCunn therefore modernized Burke's political philosophy for his Edwardian readers. Taken literally, Burke's 'conservatism' (his desire to preserve the 1688 constitution) was 'impossible' - reforms since 1832 had gone far beyond the limits which he held permissible. But this view could be modified in light of experience since his day, for example, by reading Burke in conjunction with the conscious desire from the mid-nineteenth century to produce new schemes of political legislation. ${ }^{70}$ In this way, Burke's 'reformism' was portrayed as administrative, rather than constitutional. It is here that MacCunn's disappointment with Burke is most palpable. As a Liberal, MacCunn admired Burke's organicism and acknowledged the debt of Idealism to Burke's imagination and religious feeling. He regretted, however, that Burke did not give his imagination the freedom to envisage a future ideal of constitutional and social progress. Burke was not organic enough: his aristocratic bias blinded him to the coming of an inevitable democracy. 'Its strength lies in its insistence, so eloquent, so convincing, on the unity of the whole: the weakness is that the unity is not complete. ${ }^{71}$ Quite simply, Burke's lack of commitment to democracy meant that he did not sufficiently believe

\footnotetext{
${ }^{67}$ Ibid., p. 172.

${ }^{68}$ Ibid., p. 189.

${ }^{69}$ Ibid., p. 151.

${ }^{70}$ Ibid., pp. 179-80.

${ }^{71}$ Ibid., pp. 218, 230.
} 
in the nation as an organic whole. ${ }^{72}$ Thus, whilst Burke's defence of the constitution made him a Whig in the eighteenth century, it made him a 'conservative' in 1913.

MacCunn's work was avowedly Idealist, but his reviewers reveal that by now the idea of Burke the theorist was generally established in learned society. All, whether in disciplinary journals or more popular print media, recognized that MacCunn's task had been to outline Burke's fundamental theories and their relation to modern political ideas, and many were content to approve and relay MacCunn's exposition of Burke's consistent political 'doctrine' ${ }^{73}$ G. C. Field, then Lecturer in Ethics and Politics at Manchester, was particularly impressed in his review for the International Journal of Ethics. ${ }^{74}$ MacCunn's submergence of Whiggism into conservatism was upheld in the Athenaeum which noted that Burke's 'belief in the divine right of the English Constitution of 1688 was the basis of his conservatism. ${ }^{, 75}$ Furthermore, MacCunn and Graham's texts were utilized and recommended by editors of cheap editions as well as school and university text-books. ${ }^{76}$ Hence we can see that, thanks mainly to the efforts of academic political theorists, Burke had become identified, by 1914, with a political philosophy called 'conservatism'.

III

The third part of our story is the establishment of Burke's place in contemporary political understandings of Toryism, Conservatism, and Unionism as political traditions. For Burke to truly become a 'founder of Conservatism' it was necessary for Conservative Unionists to see themselves as his intellectual heirs. The idea that Conservatism was in need of fresh historically

\footnotetext{
72 This was also the conclusion of an American reviewer, J. E. Creighton, in the Philosophical Review (Sept. 1913), pp. 558-559.

${ }^{73}$ Spectator (9 May 1913), pp. 23-4; James Gardner, 'The political philosophy of Burke', American Political Science Review (May 1914), pp. 316-318.

${ }^{74}$ G. C. Field, 'The political philosophy of Burke', International Journal of Ethics (Apr. 1914), p. 373.

${ }^{75}$ Athenaeum (29 Mar. 1913), p. 356.

${ }^{76}$ For example: Burke's speeches on America, ed. F. J .C. Hearnshaw (London, 1913); Edmund Burke, Thoughts on the cause of the present discontents, ed. W. Murison (Cambridge, 1913).
} 
and intellectually grounded traditions was not an entirely new development - some writers, such as W. H. Mallock, had already made efforts in this direction ${ }^{77}$ - but it was only after 1885 that Conservatives began to invest a large amount of energy in this area. This was intensified by the new political alignment created by the Home Rule crisis and, after 1900, by the growing prominence of the Labour movement and the associated threat of 'Socialism'. Unionists needed to survive electorally and ideologically on the new terrain, and many Conservative Unionists became disillusioned with what they perceived to be an 'unconstructive' approach to party policy. Further impetus came from the influx of Liberal Unionists, which had a profound effect on how Tories and Conservatives conceptualized their political thinking. Self-proclaimed Tories and Conservatives began to construct their own traditions and values of cautious reform and organic national harmony in an attempt to transcend class divisions. This need for political definition can be seen in high political terms through the appeals to Tariff Reform as protecting native, working-class jobs and, in another context, in the Primrose League. ${ }^{78}$ But it can also be traced at an intellectual level as numerous authors began to theorize and/or historicize Conservatism. Principal examples include F. E. Smith's Toryism (1903), Lord Hugh Cecil's Conservatism (1912), and Geoffrey Butler's The Tory tradition (1914). ${ }^{79}$ The intellectual and moral cornerstone of such texts was, more often than not, Burke.

Yet the heterogeneity of these discussions must also be recognized. This is particularly true for those who labelled themselves 'Tories' rather than 'Conservatives' - although there were no agreed definitions on what these terms actually meant. Toryism could mean 'Parson and Squire' to one writer, and democratic paternalism to another. Conservatism, on the other

\footnotetext{
${ }^{77}$ For an overview of 'Conservative' attempts at self-definition from Mallock to Thatcher, see John D. Fair and John A. Hutcheson, 'British Conservatism in the twentieth century: an emerging ideological tradition', Albion, 19 (1987), pp. 549-78.

${ }^{78}$ See Martin Pugh, The Tories and the people, 1880-1935 (Oxford, 1985).

${ }^{79}$ F. E. Smith, Toryism (London, 1903); Lord Hugh Cecil, Conservatism (London, 1912); Geoffrey Butler, The Tory tradition: Bolingbroke, Burke, Disraeli, Salisbury (London, 1914).
} 
hand, could be conceived as purely reactionary, as outright theft of Whig/Liberal policy (Peel was frequently seen to be guilty of the latter in this period ${ }^{80}$ ), or as something in between. Interestingly, many of the specifically 'Tory' writers who mourned a lost golden age before Whig or Liberal Unionist influence on the party, also went on to quote or reference Burke.

Whilst Peel remained unattractive, the legacy of Disraeli to those involved in the explicit construction of historical and intellectual Conservative canons was more valuable. Disraelian 'Tory democracy' has been portrayed as having a powerful appeal to working-class voters and to Conservatives desirous of a more 'constructive' approach to politics. Hence Ewen Green contrasts 'Disraelian Conservatism' with maintenance of the status quo, as seen in the 'pessimistic quietism' of Lord Salisbury. To Green, 'Conservative statism' proffered an organic conception of the relationship between individuals and the State, according to values of reciprocal obligation and duty. The memory of Disraeli was therefore representative of a period of reform rather than reaction. ${ }^{81}$ Indeed, this dichotomy was later promoted by Stanley Baldwin, who stated in 1933 that Conservatives could always win with Disraelian Conservatism, but not if they 'sagged into the old negative habit. ${ }^{\text {, }}$

But 'maintenance' did not mean reaction to many Conservative Unionists. Robert Taylor and Peter Marsh both suggest that Liberal Unionists would not have joined the Unionist ranks in such numbers if Conservatives had been 'incorrigible reactionaries. ${ }^{, 83}$ As Salisbury

\footnotetext{
${ }^{80}$ Smith, for instance, sneered at Peel's 'whiggism' in Toryism, p. 14. Lord Rosebery saw Peel as a Liberal: Lord Randolph Churchill (London, 1906), p. 122. Even G. Kitson Clarke's Peel and the Conservative party (London, 1929), made no claim that Peel was the founder of modern Conservatism. Instead he accepted 'that Peel may have ... possibly followed Conservative principles that did not stand the test of usefulness or time' ( $p$. xiv).

${ }^{81}$ E. H. H. Green, 'Radical Conservatism: the electoral genesis of Tariff Reform', Historical Journal, 28 (1985), pp. 667-692, at p. 690; idem., The crisis of Conservatism: the politics, economics and ideology of the British Conservative party, 1880-1914 (London, 1995), pp. 286-87.

${ }^{82}$ Philip Williamson, Stanley Baldwin: Conservative leadership and national values (Cambridge, 1999), p. 223.

${ }^{83}$ Robert Taylor, Lord Salisbury (London, 1975), p. 187; Peter Marsh, The discipline of popular government: Lord Salisbury's domestic statecraft, 1881-1902 (Sussex, 1978), p. 131. See also Roberts, Salisbury, p. 836.
} 
himself stated in 1883 , 'the object of our party is not, and ought not to be, simply to keep things as they are. ${ }^{84}$ Thus, maintenance could have an active meaning: it was a constructive process in itself. Perhaps this was rhetoric masking reaction. But, in any case, the adoption of an active conception of maintenance led to the elevation of two aphorisms from Burke's Reflections: that 'a state without the means of some change is without the means of its conservation'; and, again, 'I would not exclude alteration neither; but even when I changed, it should be to preserve. ${ }^{85}$ At the turn of the twentieth century, this sentiment was recognized as Burke's intellectual property and used with enthusiasm by many Conservative Unionists. ${ }^{86}$

Another significant intellectual development was the central position given to the French Revolution in almost all of the constructions of C/conservatism, in which the birth of modern political parties and ideas was dated from 1789. This effectively recast nineteenthcentury political thought as being formulated around responses to abstract 'principles of 1789' (liberty, equality, fraternity - the 'three-fanged serpent ${ }^{87}$ ), instead of the direct appeals to an indigenous English constitutional agenda which characterize so much of nineteenth-century political debate. ${ }^{88}$ Of course, these 'revolutionary' ideas could still be traced back to an English root. Hence another favourite analogy amongst Unionists was between Liberals and seventeenth-century puritans: anti-national, unimaginative, enemies to culture. In most cases, however, it was stated that the central ideals which framed the nineteenth century were

\footnotetext{
${ }^{84}$ [Lord Salisbury], 'Disintegration', Quarterly Review (Oct. 1883), pp. 559-595, at p. 562.

${ }^{85}$ Paul Langford and Leslie Mitchell, eds., The writings and speeches of Edmund Burke, (8 vols., Oxford, 19812000), VIII, pp. 72, 292.

${ }^{86}$ For example, William John Courthope, citing Burke, argued that Conservative 'stability' did not exclude development: 'A Conservative view: prophecy and politics', National Review (June 1886), pp. 475-86. "He is known to students, idolised by Conservatives that do not utterly disregard progress and by Liberals whose motto is 'Hasten slowly.'”: 'Edmund Burke at Beaconsfield', Speaker (16 July 1898), pp. 72-3.

${ }^{87}$ D. H. Lawrence to Bertrand Russell, 19 July 1915, The letters of D. H. Lawrence, (8 vols., Cambridge, 19792000), II, p.366.

${ }^{88}$ For an overview of nineteenth-century English/British constitutionalism, see Robert Saunders, 'Parliament and the people: the British constitution in the long nineteenth century', Journal of Modern European History, 6 (2008), pp. 72-87; for the constitution and Liberal politics, see Jonathan Parry, The politics of patriotism: English Liberalism, national identity and Europe, 1830-1886 (Cambridge, 2006), ch. 1.
} 
articulated in response to the cataclysmic political and social changes in France. In 1897, for example, Arthur Baumann cited the 'causa causans of modern Toryism' as the French Revolution, with Burke, rather than 'passive' Pitt, as its mouthpiece. Baumann, onetime Conservative MP and later editor of the Saturday Review, argued against a consistent 'Tory' tradition. Like MacCunn later, Baumann linked Burke to Conservatism because it was eighteenth-century Whiggism, not Toryism, which sought to conserve the status quo. The French Revolution united all would-be 'Conservatives', including Burke the Whig, who provided 'the creed of Conservatism [with] its highest form of expression. ${ }^{\text {, }} 9$ This was still a comparatively recent development for Conservative Unionists in 1899:

It used to be the fashion forty years ago to sneer at Burke as a madman and incendiary. But if there is anyone who can now read the 'Reflections on the Revolution in France' by the light of the world's experience with modern democracy, without being impressed by the almost superhuman wisdom of the writer, the obscurity is not in Burke's intellect but his own. ${ }^{90}$

That same year, the historian and Liberal Unionist Goldwin Smith also maintained that political parties formed themselves anew on the 'burning question' of the Revolution. ${ }^{91}$ Similarly, Blackwood's Magazine asserted that the Revolution had crystallized emerging political ideas,

\footnotetext{
${ }^{89}$ A. A. Baumann, 'An apology for unprincipled toryism', Fortnightly Review (Oct. 1897), pp. 617-25, at p. 621. See also Lord Selborne, 'Thoughts about party', Contemporary Review (Jan. 1887), pp. 2-7; William Barry, 'Edmund Burke, statesman and prophet', National Review (Jan. 1898), pp. 762-78, at p. 775; 'Mr. Pitt', Saturday Review (31 Dec. 1898), pp. 874-75.

90 'The story of the nations: modern England before the Reform Bill', Saturday Review (14 Jan. 1899), pp. 5455 , at p.54.

${ }^{91}$ Goldwin Smith, The United Kingdom, (2 vols., London, 1899), II, p. 275.
} 
and Burke's 'disposition to improve, and an ability to preserve' now expressed 'the Tory ideal. ${ }^{92}$ In tracing the roots of the Conservative party back to Burke and the French Revolution, however, an ancestry and a legacy were created which had little connection with party history as understood earlier in the nineteenth century. ${ }^{93}$

Unionist attempts to re-shape party identity around Revolutionary principles were replicated in Liberal outlets. Thus Fox became the father of Liberalism (as distinct from Whiggism) $;{ }^{94}$ ideas of nationality and democracy were traced back to 'French principles';95 and Burke was set in opposition to Rousseau ${ }^{96}$ and Paine. ${ }^{97}$ Though this latter point was not a particularly original intellectual venture, it nonetheless stressed a dualism which divided the Revolution into political binaries which were seen once again to have strong connections to the political present. Edwardian Liberals, such as Herbert Paul and J. M. Robertson, repeated Unionist assertions that the Revolution 'crystallizes' Burke's ideas which became 'more Conservative than ever. ${ }^{98}$ Henceforth one can trace 'modern English Conservatism ... in its typical form. ${ }^{99}$ We can thus see that British political traditions were reconfigured at the turn of the century. Whereas in the nineteenth century the Liberal/Conservative party polarity had been constructed around the British constitution - with Liberals favouring its reform, Conservatives favouring its defence - it became increasingly common in the Edwardian era to see the two parties (and their '-isms') as springing from different reactions to the French

\footnotetext{
92 'The Tory future', Blackwood's Magazine (Feb. 1900), pp. 182-93, at p. 188.

${ }^{93}$ Compare, for example, J. J. Sack, From Jacobite to Conservative (Cambridge, 1993).

${ }^{94}$ A. C. Forster Boulton, 'Liberalism and the Empire', Westminster Review (May 1899), pp. 486-91, at p. 488.

${ }^{95}$ C. B. Roylance Kent, The English radicals (London, 1899), pp. 82, 436-37; T. M. Kettle, The Philosophy of Politics (Dublin, 1906), p. 9.

${ }^{96}$ Malcolm MacColl, 'Lord Acton's letters to Mary Gladstone', Fortnightly Review (June 1904), pp. 996-1010, at p. 998; Edmund Gosse, 'Rousseau in England in the nineteenth century', Fortnightly Review (July 1912), pp. 22-38.

${ }^{97}$ H. A. L. Fisher, The republican tradition in Europe (London, 1911), p. 142. See also p. 89: 'what Burke said in 1790 the conservatives of Europe have believed ever since.'

${ }^{98}$ Herbert Paul, The life of Froude (London, 1905), p. 240.

${ }^{99}$ J. M. Robertson, The meaning of Liberalism (London, 1912), p. 16.
} 
Revolution. Without question, this raised the profile of Burke and explicitly connected him to the Conservatives or Unionists.

Edwardian Unionists were therefore engaged in a process of intellectual and political regeneration: the early twentieth century saw numerous publications concerned with the perceived intellectual drought within the party. Alfred Milner, Lord Hugh Cecil, Harry Roberts, F. E. Smith, Leo Amery, T. E. Hulme, Keith Feiling, and Geoffrey Butler, amongst others, all produced examinations of Toryism and/or Conservatism, depending on author preference. ${ }^{100}$ Of these texts, the works of Smith, Cecil, and Butler, were especially important in highlighting the Conservative appropriation of Burke.

F. E. Smith's Toryism (1903) was one of the first attempts to establish Burke at the head of a modern 'Tory' tradition. Smith, a rising star of the legal profession and MP for Walton from 1906, sought to represent the spectrum of political thought within his party's history through an anthology of extracts from speeches and writings. It was, like Baumann's, a history which recognized that hitherto there had been no coherent and logical body of 'Tory' doctrine. Toryism did, however, identify three embedded 'ground ideas': loyalty to the crown; devotion to the (Anglican) church; and the 'necessity of subordination'; or, social hierarchy and inequality. ${ }^{101}$ Smith admitted Burke's Whiggism as Baumann had, but insisted that the loyalty, chivalry, and opposition to parliamentary reform found in Burke's French writings 'inspired almost all that is noblest in the Toryism of later days. ${ }^{, 102}$ The Revolution found him a

\footnotetext{
${ }^{100}$ For example: Leo Amery, Union and strength (London, 1912); T. E. Hulme, 'A Tory philosophy' [1912], in The collected writings of T.E. Hulme, ed. Karen Csengeri (Oxford, 1994); Harry Roberts, Constructive Conservatism (London, 1913); F. E. Smith, Unionist policy and other essays (London, 1913); Keith Feiling, Toryism (London, 1913); idem., Tory democracy (London, 1914); Alfred Milner, The nation and the Empire (London, 1914).

${ }^{101}$ Smith, Toryism, pp. i-iii. John Campbell's otherwise substantial F. E. Smith, first earl of Birkenhead (London, 1983), only briefly mentions this publication (p. 93). By 1913 Smith had accepted 'Conservative' as the party label, noting its connection to Burke in Unionist policy, p. 3.

${ }^{102}$ Ibid., p. xlviii,
} 
'Conservative Whig' and left him a 'high Tory' ${ }^{103}$ Smith, who used the term 'Toryism' selfconsciously, concludes by saying that: 'Burke, it has been seen, had become the corner-piece of the Tory building. ${ }^{104}$ Toryism was well-received and the reviews collaborated in the blurring of Whigs and Tories. The Spectator, for instance, emphasized that Whigs and Tories, though different parties, valued similar traits of a more longstanding 'Conservatism' of order, law, and tradition. Liberalism, in contrast, preferred progress, enthusiasm, and freedom of individuality. ${ }^{105}$

However, it was not until the rejection of Lloyd George's 1909 budget by the Lords and the subsequent threat to the veto power of the Upper Chamber that Conservative Unionist writing gained considerable momentum. It was here that Burke was most systematically welcomed into the Conservative fold. In his first party conference speech as leader of the opposition in 1911, Andrew Bonar Law outlined his definition of 'Conservatism'. This was a noteworthy move for a notoriously unintellectual party leader and it is even more remarkable that he takes Burke as his guide: 'A disposition to preserve, and an ability to improve, taken together, would be my standard of a statesman.' According to Law's biographer, he frequently repeated this aphorism precisely because it came so close to enunciating his own political principles. ${ }^{106}$ Law was subsequently joined by a number of Unionists who expressed their 'Conservatism' through Burke.

The constitutional crisis also explains why Baumann saw Burke as the most relevant 'Tory' hero in 1912 as he had not in 1897. In both years he posed the same question: who should be the patron saint of Toryism? Bolingbroke or Burke? Pitt or Peel? Disraeli or Salisbury? In 1897, though 'Burkeism' was the 'only systematic body of Conservative doctrine

\footnotetext{
${ }^{103}$ Ibid., p. lix.

104 Ibid., p. lxiv.

105 Spectator (30 Jan. 1904), p. 187; Irish Times (4 Feb. 1904), p .7; Speaker (20 Feb. 1904), pp. 499-500.

106 R. Q. Adams, Bonar Law (London, 1999), p. 70.
} 
that has ever been presented to the world', at this date he nonetheless supposed that the defensive 'anti-revolutionary Toryism of Burke' was dead; and he therefore instead presented the case for a constructive Conservatism with Disraeli as the model for injecting 'Socialism' (factory, workshop, and housing acts) into Toryism. This was predicated on his assumption that the threat of 'Jacobinism' ('Irish Separatism') was minimal, although he did not rule out a return to defensive Toryism should such forces rear their head again. ${ }^{107}$ When in 1912 it became clear that such forces had returned with a vengeance, with British politics in turmoil after the 1911 Parliament Act, a recent wave of strike action and the revival of Irish Home Rule as a realistic political prospect, it is therefore no surprise that Baumann returned to Burke:

The genius of Burke seated the Tories in power for forty years. The writings of Burke contain the most complete body of Conservative doctrine, expressed in the most perfect language that has ever been given to the world. The question is whether a Tory revival, in the sense of recurrence to the Conservatism of Burke, is possible ... The greater part of Burke's philosophy, like all classical work, is detachable from the circumstances of the time ... and might have been produced in the atmosphere of Mr. Lloyd George quite as well as in that of Santerre ... The national mind must return to the mind of Burke sooner or later, because it is the only view of politics possible to men who are not mad and who are able and allowed to reason. ${ }^{108}$

\footnotetext{
${ }^{107}$ Baumann, ‘Apology for unprincipled Toryism', pp. 622-23.

${ }^{108}$ Idem., 'Is a Tory revival possible?', Fortnightly Review (Feb. 1912), pp. 217-25, at pp. 219-21. In his fourth Letter on a Regicide Peace [1795], Burke accused the Jacobin Antoine Joseph Santerre of ordering military drummers to drown out Louis XVI's final speech. See Langford et al., Writings and speeches of Burke, IX, pp. 111-12.
} 
Baumann pleaded for a little 'plain, old-fashioned, common-sense Conservatism': the restoration of the constitution, the defence of the empire, and support for the liberty of the individual and the rights of property. ${ }^{109}$ Baumann starkly separated negative 'Burkean Conservatism' and positive, Disraelian 'Tory Socialism', but he now raised defensive Burke, who remained Baumann's anti-democratic idol, to sit alongside Disraeli as a relevant Conservative thinker. ${ }^{110}$

Baumann himself went on to write Burke: The founder of Conservatism in 1929, but already in 1912 that accolade was being given to Burke by one of the most prominent of Edwardian Conservatives, Lord Hugh Cecil. Prior to 1912, Cecil, youngest son of Lord Salisbury and a first-class Oxford historian, had established himself as an articulate critic of his cousin Arthur Balfour's leadership of the party, which had lasted until 1911. As Salisbury's son, Cecil held a remarkable Conservative pedigree; but his high churchmanship and staunch independence from the party whip were seen as problematic. His motivation for separating 'Conservative' thought and the party proper was strengthened by his increasing sense of alienation from what he perceived as 'official' Unionist acceptance of Tariff Reform, which to Cecil was simply not 'Conservatism'. ${ }^{111}$ But Cecil's motivation to systematize and widely promote his views grew out of the constitutional crisis. Conservatism (1912), a volume in the Home University Library series, was written and published with a popular audience in mind. Central to its argument was the connection between Burke and both intellectual and political C/conservatism, and it devoted an entire chapter to Burke as 'the founder of conservatism'.

Cecil began by differentiating between the tenets of the Conservative party and the 'natural conservatism' which is a disposition of the human mind. They were not one and the

\footnotetext{
109 Ibid., p. 224.

${ }^{110}$ Idem., Burke: The founder of Conservatism (London, 1929).

111 The Times (15 Oct. 1905), p. 10.
} 
same, although 'modern Conservatism', or 'the Conservatism of the Conservative Party', was recruited from and dependent on the 'natural conservatism' found 'in almost every human mind.' ${ }^{112}$ For Cecil, Conservatism consisted of three elements: Toryism (reverence for religion and authority); natural conservatism (distrust of the unknown and love of the familiar); and imperialism (a feeling for the unity and greatness of Britain). ${ }^{113}$ Cecil stated that it was not until the French Revolution, however, that Conservatism was brought into existence. Before 1790 there was nothing resembling a 'Conservative doctrine.' ${ }^{114}$ When it emerged, this 'doctrine' was composed of support for 'Church and King'; for order and the status quo; and concern for the greatness and safety of England. Therefore:

In Burke Conservatism found its first and perhaps its greatest teacher, who poured forth with extraordinary rhetorical power the language of an anti-revolutionary faith, and gave to the Conservative movement the dignity of a philosophical creed and the fervour of a religious crusade ... Burke is commonly regarded as a Whig and Pitt as a Tory, but this is really a serious misapprehension. Burke was a conservative all his life. ${ }^{115}$

Again, the importance of the French Revolution in ideological and party terms was stressed, and Burke's Whiggishness was turned into 'conservatism', and thence Conservatism. For Cecil, Conservatism arose to combat Jacobinism, and henceforth the 'true division of English

\footnotetext{
112 Cecil, Conservatism, p. 8.

${ }^{113}$ Ibid., pp. 8, 244.

114 Ibid., p. 39.

115 Ibid., p. 40.
} 
parties' would relate to the principles of 1789. 'Men' were now either Jacobins or Burkeans. ${ }^{116}$ Socialists and 'new' Liberals made up the former, Unionists the latter.

To Cecil, Burke's thought was of lasting and current importance. He identified six themes in Reflections which 'permanently underlie Conservative thought.' These were: the importance of religion and the value of its recognition by the state; the hatred of injustice to individuals committed in the course of political and social reform; the attack on the revolutionary conception of equality which suppressed the reality and necessity of rank and distinctions; the sanctity of private property and its beneficial contribution to society; the idea that human society is an organism, of which much is mysterious; and therefore, finally, the importance of continuity with the historical past and of making any change as gradual and with as slight dislocation as possible. ${ }^{117}$ Here we have the reduction of Burke into a six-point 'Conservative' political theory. Throughout the book, Cecil goes back repeatedly to Conservatism's opposition to Revolutionary principles as the foundation for the twin beliefs in religion and property. ${ }^{118}$ The high churchman Cecil stated that the religious basis of Conservatism provided a sense of revulsion against injustice, and this was the logic of 'Conservative' social reform. ${ }^{119}$ Cecil also argued in favour of bipartisan Lords reform, suggesting a preserving scheme which would allow for change in keeping with the existing traditions of the second chamber. ${ }^{120}$ This was, no doubt, an active approach to 'maintenance'.

Cecil's work was eagerly received. The philosopher C. D. Broad stated in the International Journal of Ethics that Conservatism was considered an 'event' at the time due to

\footnotetext{
116 Ibid., pp. 44, 248.

${ }^{117}$ Ibid., p. 48.

118 Ibid., pp. 114, 118

119 This drew on a long tradition of high church social concern, stretching back to the Oxford Movement. For its origins, see Simon Skinner, Tractarians and the 'Condition of England': the social and political thought of the Oxford Movement (Oxford, 2004).

${ }^{120}$ Ibid., p. 233.
} 
the 'general paucity of literature on the history and character of British conservatism.' ${ }^{121}$ The Athenaeum and the English Review also noted the value and interest of Cecil's book, as 'philosophical conservatism is for some inexplicable reason less defined than philosophic liberalism. ${ }^{122}$ Baumann, in the Fortnightly Review, stressed the relevance of Burke yet again. ${ }^{123}$ Once more, Baumann and the Review of Reviews affirmed that 'Conservatism' was a consequence of the French Revolution. ${ }^{124}$ The Saturday Review, however, was hostile to Cecil's attempts to theorize practical politics. ${ }^{125}$ Indeed, the idea of 'conservative political philosophy' continued to be much more contested than that of liberalism or socialism, and Cecil himself was a controversial figure, thanks to his unconventional parliamentary behaviour, which had him and his supporters branded 'Hughligans'. ${ }^{126}$ Silences are, however, important: none of the reviews disagreed with Cecil's assertion that the founder of 'modern conservatism' was a Whig named Burke.

The final text to be considered is Geoffrey Butler's The Tory tradition: Bolingbroke, Burke, Disraeli, Salisbury (1914). Butler, first-class Cambridge historian, Fellow of Corpus Christi College, Cambridge, and uncle of the Home Secretary R. A. Butler, had also produced a political tract for the times. In his Tory Tradition Bolingbroke became the great Tory party leader, with both destructive and constructive abilities. Burke was the most profound Tory political philosopher. ${ }^{127}$ Disraeli, 'the greatest of all Tories', combined romantic imagination with pragmatic political skill, whose ideal was a national Toryism, with an enfranchised people

\footnotetext{
${ }^{121}$ C. C. Broad, 'Lord Hugh Cecil's Conservatism', International Journal of Ethics (July 1913), p. 396. See also William S. Rodner, 'Conservatism, Resistance and Lord Hugh Cecil', History of Political Thought, 9 (1988), pp. 529-551.

${ }^{122}$ English Review (July 1912), pp. 668-69; Athenaeum (4 May 1912), p. 502.

${ }^{123}$ A. A. Baumann, 'Lord Hugh Cecil on Conservatism', Fortnightly Review (July 1912), pp. 39-52.

${ }^{124}$ Review of Reviews (July 1912), pp. 108-9.

${ }^{125}$ Saturday Review (27 July 1912), pp. 115-16.

${ }^{126}$ Rodner, 'Conservatism, resistance and Lord Hugh Cecil', p. 537; Richard A. Rempel, 'Lord Hugh Cecil's parliamentary career, 1900-1914: promise unfulfilled', Journal of British Studies, 11 (1972), pp. 104-30.

${ }^{127}$ Butler, The Tory tradition, p. 23, 103.
} 
and a Patriot King, which could effectively ward off factional interests and garner the support of the working classes. ${ }^{128}$ Lord Salisbury was, in 1914, held up as a great conciliatory diplomat: quietly confident, with an historical approach to addressing oppression which was an 'active weapon' (and not a 'passive accomplishment'). ${ }^{129}$ Each had left their legacy to modern Tories.

Butler, though stating Burke's overall consistency, argued for the unique importance of the French Revolution in bringing out the Conservatism of his thought. To concentrate upon Burke's opposition to the Revolution was to do what was 'most useful' in a systematic study of the growth of Tory doctrine. ${ }^{130}$ Burke's 'doctrine', according to Butler, of the organic, as opposed to mechanical, conception of society, was 'the fundamental doctrine of all Toryism. ${ }^{131}$ Burke also shared the 'Tory disbelief' in infinite individual capabilities and trust in inherited methods of government. He was: 'almost the only English political philosopher who rejected the a priori method. ${ }^{132}$ Burke was therefore urged as an essential modern guide:

The Tory must draw upon the wisdom of our Fathers, he must select and he must reinterpret their sacred principles in a language understood of the people. There must be a Renaissance, a Reformation, a Reception of unexampled brilliance and of unparalleled effect ... "Back to Burke", "An open Burke". He must be the Bible of a pure and reformed Conservatism, which alone can oust the misguided if generous proposals of the modern Radicals, and meet and solve the problems which have given those proposals motive force. ${ }^{133}$

\footnotetext{
${ }^{128}$ Ibid., p. 60-7.

${ }^{129}$ Ibid., 116.

${ }^{130}$ Ibid., p. 33-4.

${ }^{131}$ Ibid., p. 40.

132 Ibid., p. 47.

${ }^{133}$ Ibid., p. 59.
} 
The Tory tradition was well-received. The Athenaeum was congratulatory in its review, and regretted that the English had been apt to forget the 'constructive side of Toryism.' ${ }^{134}$ The major u-turn came from the Saturday Review, which had been generally critical of Unionist and Liberal attempts to talk about Burke's 'political philosophy'. Butler was certainly a less controversial author than Cecil and, perhaps as a result, the Saturday was now laudatory and recommended Butler's text on the contemporary relevance of Burke in particular. The Saturday did, however, question the appropriateness of the label 'Tory', and instead suggested that there would be no disagreement over designating Burke a 'Conservative.' 135

IV

The late-Victorian and Edwardian period saw the construction of political traditions of an entirely novel kind. It was thanks to this process that Burke could be claimed as the 'founder of modern conservatism', where conservatism is the basis of both a party-political and a more abstract political-philosophical tradition. Our modern conception of 'Burkean conservatism' was thus a product of late nineteenth- and early twentieth-century intellectual history. Yet, despite being analytically and polemically powerful, political traditions are rarely historicized in this way.

The debates over Irish Home Rule and Gladstone's call for consideration of Burke's work made his writings a living force - hereafter he was not simply a great political writer, but an intensely relevant one. The 'essence' of Burke's thought became a subject of heated debate, and it gradually but decisively became associated with the Liberal Unionists, who resurrected

\footnotetext{
${ }^{134}$ Athenaeum (26 Dec. 1914), p. 666.

${ }^{135}$ Saturday Review (16 Jan. 1915), pp. 64-65.
} 
an anti-Jacobin vocabulary and styled themselves as Old Whigs defending the constitution. By 1893, their Conservative allies were significantly more comfortable quoting speeches which until recently had been Gladstonian territory. But this process was not merely governed by high politics: the general intellectual climate, as Morley had foreseen, was ripe for a re-interpretation of Burke's oeuvre which stressed the organic, historical, and developmental nature of his thought. Moreover, this was increasingly framed in more philosophical (though never strictly defined) terminology of 'doctrine', 'theory' and 'political philosophy'. Burke's essential consistency of principles was acknowledged equally by the Liberals Graham, Keynes, and MacCunn, and his Conservative appropriators Baumann, Smith, Cecil, and Butler. The example of MacCunn, in particular, highlights Idealism's role in welding ideas of organicism to conservatism. Paradoxically, therefore, Burke's heyday as an organic historicist thinker also led to his abstraction from his original historical context.

It was also from c.1885-6 that modern ideologies of 'C/conservatism' and 'L/liberalism' were routinely traced back to the French Revolution. This marked an important departure from the post-1832 (British) constitutional agenda. It enabled the blurring of Burke's Whig identity into newly constructed categories of 'C/conservatism', which were seen to have crystallized in opposition to the principles of 1789, during a period in which fears of British and Irish Jacobins attacking property, religion, and the constitution came back to life. This was helped, of course, by the fact that many former Whigs were now allied politically with Conservatives in the Unionist party. It is also here that one can see the continuing centrality of constitutional maintenance to Conservative thought and the party proper.

Still, there remains an unresolved contradiction in both the 'theoretical' and political discussions of Burke and C/conservatism. On the one hand, Burke symbolized historicallyinformed organic C/conservatism, which would reform - within boundaries - to preserve national values and institutions. He was a 'political philosopher' who valued beneficial 
outcomes over strict adherence to abstract principles. Thus, the idea of 'maintenance' of the constitution, property, and 'religion' could have an active, constructive meaning. On the other hand, Burke was seen as intellectual ammunition: a defensive weapon against democratic Jacobins who would radically reform the constitution. The result was therefore not conceptually clear cut, but then neither Burke's works nor British political debate had ever been theoretically rigorous. In short, Burke was enlisted to support different approaches depending on what the specific situation required.

The overall result was that Burke, a Whig statesman cherished in the mid-nineteenth century more for his powers of rhetoric than his principles, was increasingly regarded as a great Conservative and/or Tory philosopher across the political spectrum in a way that was quite unlike earlier discussions of his life and thought. By 1914, all of the components of the modern understanding of 'Burkean conservatism' listed at the beginning of this article were routinely identified as forming the basis of Burke's newly systematized 'political philosophy'. There was widespread agreement that the intellectual and political traditions of an organic historicist 'C/conservatism' had come into being in 1790 with the publication of Burke's Reflections. In fact, it might be more accurate to say that both British Conservatism and conservatism, as significant bodies of thought, came into being in the years 1885 to 1914 - and it was this which raised Burke into the canonical position he still enjoys as 'the founder of modern conservatism'. 